\title{
Seasonal and inter-annual oceanographic changes induce diet switching in a piscivorous seabird
}

\author{
Motohiro Ito $^{1, *}$, Hiroshi Minami ${ }^{2}$, Yuzan Tanaka ${ }^{1}$, Yutaka Watanuki ${ }^{1}$ \\ ${ }^{1}$ Graduate School of Fisheries Sciences, Hokkaido University, 3-1-1 Minato, Hakodate, Hokkaido, 041-8611, Japan \\ ${ }^{2}$ National Research Institute of Far Seas Fisheries, 5-7-1 Shimizu, Shizuoka, 424-8633, Japan
}

\begin{abstract}
The structure of a marine food web can change quickly within seasons as well as interannually in response to physical oceanographic changes. In this study, we examined the relationship between temporal changes in the marine ecosystem of northern Hokkaido, Japan, and diets of rhinoceros auklets Cerorhinca monocerata breeding in this region. To obtain an integrated measure of changes in diet composition on short (days) and inter-annual (2004 and 2005) time scales, we used a 2-pronged approach. We examined (1) the diets of adults using stomach contents and stable isotope signatures in tissues, and (2) chick diets using the composition of bill-loads delivered to chicks. During the incubation period, the diet of adults comprised euphausiids (Thysanoessa longipes and T. inermis). During the chick-rearing period, the diet of adults was age 0 Japanese sandlance Ammodytes personatus and age 0 Japan Sea greenling Pleurogrammus azonus in the early period, but switched quickly $(<10$ d) to warm-water-preferring Japanese anchovy Engraulis japonicus when the warm Tsushima Current intruded into their foraging range. Adult blood plasma stable isotope ratios reflected these seasonal changes in stomach content. Diets did not differ between age categories. Furthermore, the timing of diet switching to anchovy differed inter-annually, and was about $10 \mathrm{~d}$ later in 2005 than 2004, reflecting a difference in the timing of the intrusion of warm water. We conclude that rhinoceros auklets respond sensitively to current-related rapid marine food web changes.
\end{abstract}

KEY WORDS: Prey switching · Stable isotope signatures · Rhinoceros auklets · Anchovy · Tsushima Current

- Resale or republication not permitted without written consent of the publisher

\section{INTRODUCTION}

The structure of a local marine food web can change quickly both seasonally and inter-annually in response to physical oceanographic changes (i.e. current systems and seasonal upwelling). The resulting seasonal and inter-annual changes in prey availability can then affect the breeding performance of seabirds, which are marine top predators, through trophic effects (Guinet et al. 1998, Kitaysky \& Golubova 2000, Durant et al. 2003, Gjerdrum et al. 2003, Boyd et al. 2006, Wanless et al. 2007). Knowledge on how seabirds respond to physical oceanographic changes may shed light on the trophic effects induced by physical oceanographic changes on seabird breeding, one of the driving mechanisms of the population dynamics of marine top predators. To investigate the interaction between seabirds and marine resources, and rapid seasonal and inter- annual ecosystem changes, it is important to collect unbiased information on their diet over short time scales (1 to 3 d).

Previous studies have often surveyed diets provisioned to seabird chicks, as these data are easily collected (Harris \& Wanless 1985, Watanuki 1987, Barrett \& Furness 1990, Burger et al. 1993, Lewis et al. 2001, Litzow et al. 2002). However, the diets of adults have not been studied as much, since they are difficult to sample without sacrificing the birds (Gaston \& Jones 1998). Several studies have suggested that adult seabirds, as central place foragers (Orians \& Pearson 1979), feed chicks with large and higher quality prey, such as age $>1(>1+)$ sandlance or age $>1$ herring, while adults fed themselves on smaller, more easily collected prey, such as age $0(0+)$ sandlance or euphausiids (Gaston \& Nettleship 1981, Ydenberg 1994, Butler \& Buckley 2002, Wilson et al. 2004). If adults select dif- 
ferent prey types for their chicks and themselves, seasonal and inter-annual oceanographic changes may affect adults and chicks differently. Furthermore, adult diet during egg formation and incubation is likely to be critical in determining the timing of breeding, clutch size, egg quality, and parental body condition in seabirds (Chastel et al. 1995, Oro et al. 1996, Barbraud \& Chastel 1999, Gasparini et al. 2007). Thus, prey availability before hatching strongly affects fitness. Therefore, to gain an improved understanding of the relationships between seabirds and marine ecosystems, the diets of adults and chicks should be analyzed throughout the whole breeding season, including the egg-formation and incubation periods.

Sampling of stomach contents by the non-lethal water offloading technique has been done in many species of penguins and procellariiforms that transport food in their stomachs (Wilson 1984, Bost et al. 1994, Cherel et al. 1996), but few studies have been done with alcids that transport food in their bills (Wilson et al. 2004). The stable isotope ratio of blood plasma and egg yolk also provides information on the average trophic level of a bird's diet over a few days to $1 \mathrm{wk}$, while these tissues were formed (several days before sampling for blood plasma and the egg-formation period for egg yolk), without digestion biases (Hobson 1993, 1995, Hobson \& Clark 1993, Hobson et al. 1994, Forero \& Hobson 2003). Therefore, integrating information on the stomach contents of adults, stable isotope ratios of blood plasma or that of egg yolk, and billloads for chicks should be useful for monitoring the diets of both adults and chicks throughout the breeding season.

In the Sea of Japan, the seasonal northern expansion of the Tsushima Warm Current (Naganuma 2000, Nakata \& Tanaka 2002) is believed to have a strong influence on the marine ecosystem during spring and summer. Along the coast of Hokkaido, sea surface temperature (SST) rises from $3^{\circ} \mathrm{C}$ to $20^{\circ} \mathrm{C}$ over 4 mo (March to August). As a result, the marine food web changes drastically. For example, a phytoplankton bloom occurs in early spring (Tameishi et al. 1999). In March and April, swarms of spawning euphausiids form at the sea surface when the SST increases to $4^{\circ} \mathrm{C}$, and disperse when the SST further increases to $8^{\circ} \mathrm{C}$ (Hanamura et al. 1989). The distribution of warm-water-preferring Japanese anchovy Engraulis japonicus is also affected by the northward expansion of the warm water (Nagasawa \& Torisawa 1991). This area therefore provides a suitable system in which to examine the influences of marine food web changes, induced by physical oceanographic changes, on the diets of marine top predators.

The rhinoceros auklet Cerorhinca monocerata is a medium-sized (480 to $620 \mathrm{~g}$ ) alcid that breeds in tem- perate waters in the North Pacific (Gaston \& Jones 1998). It feeds on various pelagic fish species (Thayer \& Sydeman 2007). About 291000 pairs breed on Teuri Island in the northern part of the Sea of Japan (Osa \& Watanuki 2002).

The diets of rhinoceros auklet chicks have been repeatedly monitored on Teuri island (Watanuki 1987, Takahashi et al. 2001, Deguchi et al. 2004). It is known that rhinoceros auklets bring back Japanese sandlance Ammodytes personatus and Japan Sea greenling Pleurogrammus azonus to their chicks early in the chickrearing period, and then change their prey to Japanese anchovy, which are large and energy-rich, hence important for chicks, in the middle of chick rearing (Takahashi et al. 2001). The timing of arrival of anchovies in the surrounding waters may thus determine chick growth and fledging success of rhinoceros auklets on Teuri Island (Takahashi et al. 2001, Deguchi et al. 2004). However, the diets of adult auklets throughout the breeding season, including the eggformation and incubation periods, are unknown. Diet during the chick-rearing period could differ between adults and chicks, as suggested by a previous study (Davoren \& Burger 1999). Understanding the mechanisms of the short-term seasonal changes in their diet throughout the breeding season could help to clarify the trophic effects of local physical oceanographic changes on seabird breeding.

To investigate the diet of adults and chicks throughout the breeding season of 2004 and 2005, with different seasonal patterns of the Tsushima Current, we analyzed the stomach contents of adults collected by water off-loading; by using the stable isotope ratios $\left(\delta^{15} \mathrm{~N}\right.$, $\delta^{13} \mathrm{C}$ ) of adult blood plasma and of egg yolks; and by investigating chick diet as bill-loads. We predicted that adults would feed themselves on small prey species, including euphausiids that are presumably easier to acquire, and that they would switch chick diets from sandlance and greenling to anchovy, which are large and nutritious prey for chicks, when they became available during the summer due to an intrusion of the warm Tsushima Current. The degree and timing of the northern expansion of warm water, which can vary both seasonally and inter-annually, may induce seasonal and inter-annual changes in the local marine food web and influence the prey selection of rhinoceros auklets, a marine top predator.

\section{MATERIALS AND METHODS}

Field work. The field work was carried out between late April and late July of 2004 and 2005 on Teuri Island $\left(44^{\circ} 25^{\prime} \mathrm{N}, 142^{\circ} 19^{\prime} \mathrm{E}\right), 28 \mathrm{~km}$ off Haboro, northern Hokkaido. The rhinoceros auklets breed on the 
grassy shoulder slopes of the cliffs along the northwest side of the island. Rhinoceros auklets make burrows more than $1 \mathrm{~m}$ deep in the soil, lay eggs in early April, incubate until mid-May, and bring back food for chicks from mid-May to late July (Watanuki 1987). Adults change incubation duties almost every night and bring back bill-loads of food for chicks every night (Gaston \& Jones 1998, Takahashi et al. 1999).

Every 2 or 3 d, between 19:30 and 21:30 h, 3 to 4 adults coming back to the nesting sites near the Akaiwa lighthouse were captured by hand or with nets. Those having apparent brood patches or those bringing bill-loads were captured to minimize the possibility of capturing non-breeders. Blood and stomach contents were sampled during the incubation period. After chick hatching, bill-loads were also sampled in addition to blood and stomach contents. In this study, the breeding season was separated into the incubation (30 April to 18 May in 2004, 20 April to 12 May in 2005), early chick-rearing (30 May to 2 June in 2004, 23 May to 9 June in 2005), and late chick-rearing (3 June to 20 July in 2004, 11 June to 19 July in 2005) periods.

In 2004 and 2005, 92 and 145 birds were captured, respectively. About $50 \mathrm{ml}$ warm $\left(\mathrm{ca} .35^{\circ} \mathrm{C}\right.$ ) water was introduced into the proventriculus of these birds using a funnel with a $13 \mathrm{~mm}$ diameter, $50 \mathrm{~cm}$ length elastic tube. The water and stomach contents were flushed into a bucket by gently pushing the belly of the birds. The procedure was repeated at most 3 times until the offloaded water became clear. About $1 \mathrm{ml}$ of blood was sampled from the brachial vein of 24 and 67 birds in 2004 and 2005, respectively, using a heparinized syringe. The blood was kept in $1.5 \mathrm{ml}$ microtubes and brought back to the field station in a cooler box with ice. It was centrifuged at $2000 \times g$ for $10 \mathrm{~min}$ to separate blood cells and plasma. Blood samples were kept at $-30^{\circ} \mathrm{C}$. During the chick-rearing period, bill-loads were sampled, identified, and measured at the station, then kept at $-30^{\circ} \mathrm{C}$.

Ten eggs of rhinoceros auklets were collected from their nests on 20 April 2005, during the egg-laying season. Egg yolks were separated and then kept at $-30^{\circ} \mathrm{C}$.

Analyses of stomach contents and bill-loads. Stomach samples were drained using $0.33 \mathrm{~mm}$ mesh filter in the field station and preserved in 70\% 2-propanol. Prey was identified to the lowest taxon level possible using reference vertebrae of fish and identification guides (Nakabo 1993, Chihara \& Murano 1997). Among 92 and 145 stomach samples, 81 and 86 samples contained identifiable items in 2004 and 2005, respectively. By referring to the size of vertebrae, 0 -yearold $(0+)$ sandlance were separated from $>1$-year-old $(>1+)$ sandlance. The total length of euphausiids in the stomach contents was measured if possible.
Bill-loads were collected from 62 and 82 adults in 2004 and 2005, respectively. Each prey item was identified to species, and its fork length (fish) or mantle length (squid) and body mass were measured. Sandlance $>110 \mathrm{~mm}$ in fork length were classified as age $>1+$ class and those $<110 \mathrm{~mm}$ were the $0+$ age class, and Japan sea greenling $<180 \mathrm{~mm}$ were classified as the 0+ age class (Takahashi et al. 2001, Ishikawa \& Watanuki 2002). Anchovies were all $>130 \mathrm{~mm}$ and mature so we did not classify the anchovies into age classes.

Analyses of stable isotope ratios. The $\delta^{15} \mathrm{~N}$ and $\delta^{13} \mathrm{C}$ of blood plasma (samples in 2004 and 2005), egg yolk (sampled only in 2005), and those of potential prey including the euphausiid Thaysanoessa inermis, squid Coleoides, $0+$ and $>1+$ sandlance Ammodytes personatus, and 0+ Japan Sea greenling Pleurogrammus azonus were measured following Hobson (1993). Euphausiids were sampled by bongo net $(0.33 \mathrm{~mm}$ mesh aperture, $60 \mathrm{~cm}$ mouth diameter) in the surrounding water on 10 May 2003 by the RV 'Tankai Maru' (National Fisheries Research Institute, Fisheries Research Agency). Other prey items were collected from bill-loads in 2004 and 2005.

Blood plasma and egg yolks were dried at $60^{\circ} \mathrm{C}$ in an electric oven for $24 \mathrm{~h}$, then ground to a powder. Euphausiids, 0+ sandlance, $>1+$ sandlance, 0+ greenling, anchovy, and squid were minced, dried, and ground similarly. Lipids were extracted from prey tissues using a chloroform:methanol (2:1) solvent rinse and then dried at $60^{\circ} \mathrm{C}$ for $24 \mathrm{~h}$ to remove any residual solvent. Extraction of lipids was not necessary for blood samples because the lipid component in blood is generally low (Deuel 1955). Samples were kept at $-30^{\circ} \mathrm{C}$ before stable isotope analyses.

Stable carbon and nitrogen compositions of the samples were determined using a mass spectrometer (MAT 252, Finnigan MAT) coupled online via a Finnigan ConFlo II interface with an elemental analyzer (EA 1110, ThermoQuest). Subsamples (1 mg) of homogenized materials were loaded into tin cups and combusted at $1000^{\circ} \mathrm{C}$. The resultant $\mathrm{CO}_{2}$ and $\mathrm{N}_{2}$ gases were then analyzed. Pee Dee Belemnite (PDB) collected in South Carolina, USA, and atmospheric $\mathrm{N}_{2}$ were used as standards following Hobson (1993). Stable isotope concentrations were expressed in $\delta$ notation as parts per thousand according to the following equation:

$$
\delta^{15} \mathrm{~N} \text { or } \delta^{13} \mathrm{C}=\left[\left(R_{\text {sample }} / R_{\text {standard }}\right) \times 1\right] \times 1000
$$

where $R=$ the corresponding ratio ${ }^{13} \mathrm{C} /{ }^{12} \mathrm{C}$ or ${ }^{15} \mathrm{~N} /{ }^{14} \mathrm{~N}$. $R_{\text {standard }}$ for ${ }^{13} \mathrm{C}$ and ${ }^{15} \mathrm{~N}$ is that for PDB and atmospheric $\mathrm{N}_{2}$ standard, respectively. Calcium or sodium carbonate for $\delta^{13} \mathrm{C}$ and high-purity $\mathrm{N}_{2}$ gas for $\delta^{15} \mathrm{~N}$ were also used as working standards during isotope measure- 
ments. The analytical precision $( \pm \mathrm{SD})$ of these measurements is estimated to be $\pm 0.1 \%$ o for carbon and $\pm 0.3 \%$ o for nitrogen.

Stable isotope enrichment factor in plasma and egg yolk. We estimated the trophic level of adult rhinoceros auklets assuming that the enrichment factor in adults was the same as that in chicks. To determine the enrichment factor of carbon and nitrogen in the blood plasma in chicks, we collected 3 eggs and hatched these in an incubator (P-008A, Syowa Furanki), and then fed chicks with $60 \mathrm{~g}>1+$ sandlance every day until fledging ( 45 to $50 \mathrm{~d}$ old). Blood samples were collected at $40 \mathrm{~d}$ of age. $\delta^{13} \mathrm{C}$ and $\delta^{15} \mathrm{~N}$ were $-18.7 \%$ and $13.7 \%$ for blood plasma and $-17.4 \%$ and $10.9 \%$ for diet, respectively. Therefore, enrichment factors were $-1.3 \%$ and $2.8 \%$ o for $\delta^{13} \mathrm{C}$ and $\delta^{15} \mathrm{~N}$, respectively.

Enrichment factors differ among different types of bird tissues (Hobson \& Clark 1992a,b, Hobson 1995). To allow the comparison of analyses of several types of bird tissue, stable isotope ratios in each tissue were modified by the enrichment factor of their tissues (e.g. Hobson et al. 1994). Thus, to compare stable isotope ratios in blood plasma and egg yolk, stable isotope ratios in egg yolk $(x)$ were adjusted using the enrichment factor of blood plasma $(y)$ and that of egg yolk $(z)$ (adjusted value: egg yolk $=x-z+y$ ). The enrichment factor for egg yolk in rhinoceros auklets was unknown, so we used the average enrichment factor in lipid-free egg yolk of 6 avian species $\left(\delta^{13} \mathrm{C}: 0.1 \%\right.$, $\delta^{15} \mathrm{~N}$ : $3.4 \%$; Hobson 1995).

Sea surface temperature. As the local SSTs around the northern Sea of Japan, we used the daily SSTs based on satellite data (AVHRR sensor on the NOAA satellite and AMSR-E sensor on the AQUA satellite, analyzed by the Japan Meteorological Agency, available in the NEAR-GOOS database, JODC: http:// near-goos1.jodc.go.jp/index.html). Daily SSTs at the southern edge of the foraging range of rhinoceros auklets (western Shiribeshi rigion), that around Teuri Island (northern Rumoi region), and that at the northern edge of the foraging range of auklets (Soya region), and mean daily SSTs (satellite data) in the area shown in Fig. 5A-C, were obtained from the Hakodate Marine Observatory (www.data.kishou.go. jp/kaiyou/db/hakodate/finesstHK/finesstHK.html).

Statistics. The daily patterns of prey occurrence during the chick-rearing period were compared between 2 age classes, chicks and adults, using the Kolmogorov-Smirnov test for each prey item. The occurrence of $0+$ sandlance, $>1+$ sandlance, greenling, and anchovy between the stomach contents and bill-loads during the chick-rearing period was compared by a chi-squared test. The $\delta^{15} \mathrm{~N}$ and $\delta^{13} \mathrm{C}$ were compared among seasons (egg-formation period: adjusted value of egg yolk, incubation period: blood plasma, early chick-rearing and late chick-rearing period: blood plasma) and years using 1-way analysis of variance (ANOVA) with Scheffé's post hoc test.

We defined the date of the prey switching as the date when $50 \%$ of the auklets brought and fed on anchovy. To determine the date of prey switching, we used logistic regression analyses. Each bill-load and stomach was assigned to 'anchovy' (1) if it contained anchovy or 'non-anchovy' (0) if it did not (Fig. 1). The same analysis to define the date of prey switching was also conducted for euphausiids, assigned as 'euphausiid' (1) or 'non-euphausiid' (0) (Fig. 1). Among all bill-loads, 95.8\% consisted of a single prey species and $4.2 \%$ consisted of 2 prey fish species. Among all stomachs, 91.1\% contained only a single prey species. Thus bill-loads and stomach contents were easily assigned to anchovy and non-anchovy or euphausiid and non-euphausiid. For these analyses, the dates of sampling were calculated from 1 April. The date of prey switching was calculated from the regression equations. StatView (ver. 5.0, SAS) was used for all statistical analyses.

\section{RESULTS}

\section{Seasonal changes of adult and chick diets}

Adult auklets fed on euphausiids only during the incubation period in both 2004 and 2005. In 2004, Thysanoessa longipes (no measurable individual was included) were found in stomach contents, and in 2005, $T$. inermis (32 to $35 \mathrm{~mm}$ in total length, $\mathrm{n}=8$ ) were found. During the early chick-rearing period, adults fed themselves on various fish species (squids, 0+ sandlance, >1+ sandlance, 0+ Japan Sea greenling) and then switched to anchovy (Table 1). In bill-loads for chicks, squids $(6.7 \pm 2.9 \mathrm{~g}, 89.5 \pm 19.1 \mathrm{~mm}), 0+$ sandlance $(0.7 \pm 0.5$ g, $59.3 \pm 8.6 \mathrm{~mm}), 0+$ Japan Sea greenling $(7.3 \pm 4.9 \mathrm{~g}, 97.9 \pm 21.6 \mathrm{~mm})$, and anchovy $(23.8 \pm$ $4.8 \mathrm{~g}, 137.7 \pm 6.8 \mathrm{~mm}$ ) were found both in 2004 and 2005 (Table 1).

During the chick-rearing period, there were no significant differences in the occurrence of $0+$ sandlance, greenling, and anchovy between adult and chick diets $\left(\chi^{2}\right.$-test: 2004, $\chi^{2}=0.30, p=0.86 ; 2005, \chi^{2}=3.30, p=$ 0.19 , Table 1$)$. The daily patterns of the occurrence of prey items in adult and chick diets also did not differ significantly (Table 2).

Among stomach samples of parents that provided bill-load samples, 61 contained identifiable prey items both in 2004 and 2005. Most stomach samples and billloads comprised a single prey species. One of 62 billloads and 4 of 61 stomach samples contained more than 2 prey species in 2004, and 5 of 82 bill-loads and 3 of 61 stomach samples contained more than 2 prey species in 

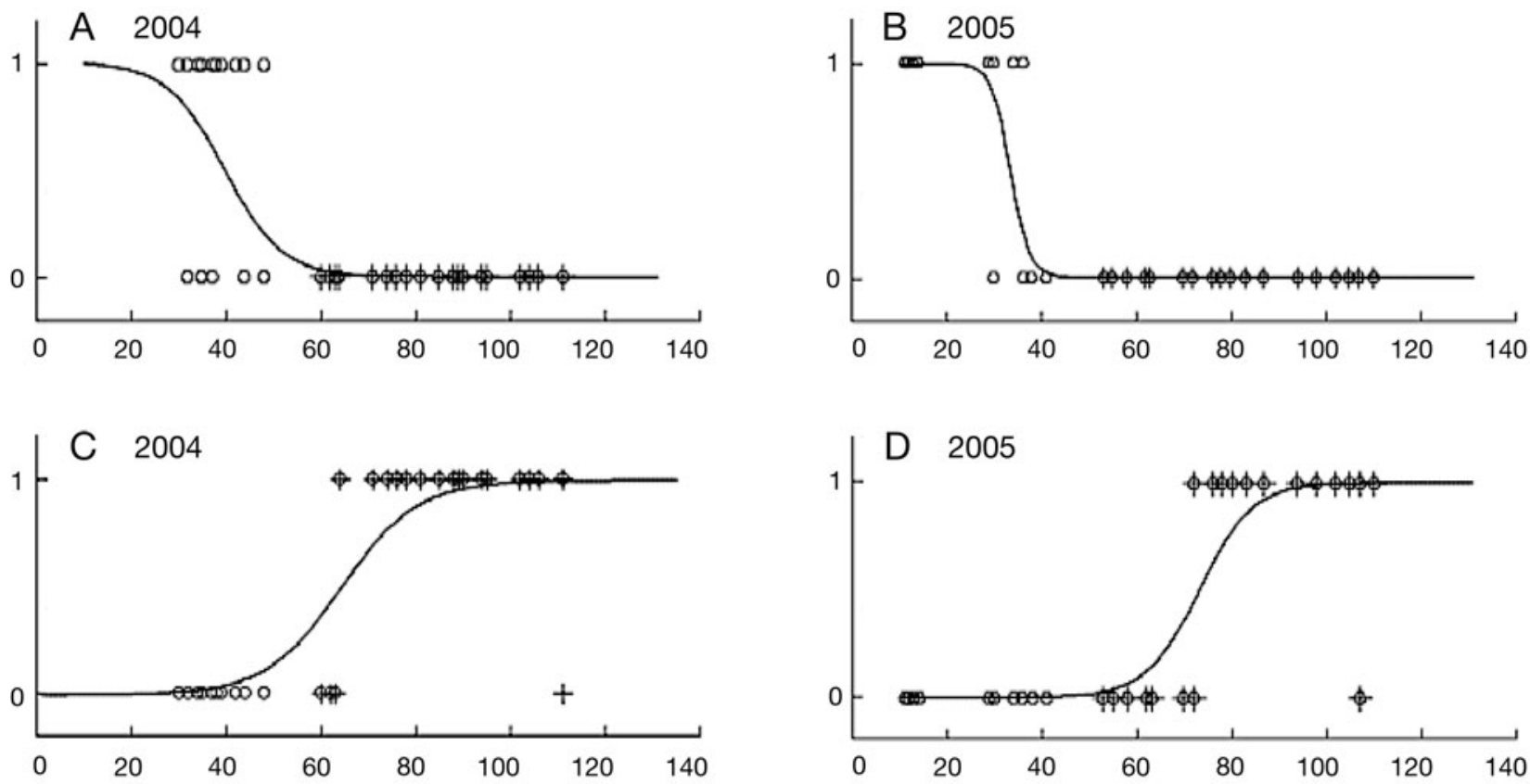

Days after April 1

Fig. 1. Cerorhinca monocerata. Seasonal change in the occurrence of euphausiids and anchovy from stomachs and bill-loads of auklets in 2004 and 2005. Date of sampling was calculated from 1 April. (A,B) Occurrence of euphausiids (designated as 1) and that of non-euphausiids (designated as 0 ) in stomachs $(O)$ and bill-loads $(+)$. (C,D) Occurrence of anchovy (1) and that of nonanchovy $(0)$ in stomachs $(O)$ and bill-loads $(+)$. Logistic regressions are all significant and are shown as thin lines

2005. In 58 of 61 birds, bill-loads and their stomach samples contained the same prey species, both in 2004 and 2005, indicating that parents fed themselves on the same prey as they provided for their chicks.

As seasonal patterns in the occurrence of prey types in bill-loads and stomachs were quite similar, these were combined to determine the timing of prey switching. During the incubation period, parents switched from euphausiids to non-enphausiids on Day 33 (3 May) in 2004 and Day 39 (9 May) in 2005 (Fig. 1). During the chick-rearing period, parents switched prey to anchovy on Day 65 (4 June) in 2004 and on Day 75 (14 June) in 2005 (Fig. 1). The duration between the time when anchovy first appeared in bill-loads and the time when $50 \%$ of parents brought back anchovy was only 8 d in 2004 and 10 d in 2005 (Fig. 1).

Table 1. Cerorhinca monocerata. Percentage occurrence of each prey item found in adult stomachs and bill loads for chicks in 2004 and 2005

\begin{tabular}{|c|c|c|c|c|c|c|c|c|c|c|c|c|c|c|}
\hline Stage & \multicolumn{2}{|c|}{$\begin{array}{l}\text { Euphausiid } \\
\text { Bill Stomach } \\
\text { load }\end{array}$} & \multicolumn{2}{|c|}{$\begin{array}{l}\text { 0+ Sandlance } \\
\text { Bill Stomach } \\
\text { load }\end{array}$} & \multicolumn{2}{|c|}{$\begin{array}{l}>1+\text { Sandlance } \\
\text { Bill Stomach } \\
\text { load }\end{array}$} & \multicolumn{2}{|c|}{$\begin{array}{l}\text { Greenling } \\
\text { Bill Stomach } \\
\text { load }\end{array}$} & \multicolumn{2}{|c|}{$\begin{array}{l}\text { Squid } \\
\text { Bill Stomach } \\
\text { load }\end{array}$} & \multicolumn{2}{|c|}{$\begin{array}{l}\text { Anchovy } \\
\text { Bill Stomach } \\
\text { load }\end{array}$} & \multicolumn{2}{|c|}{$\begin{array}{l}\text { Sample size } \\
\text { Bill Stomach } \\
\text { load }\end{array}$} \\
\hline 2004 & & & & & & & & & & & & & & \\
\hline Incubation & - & 61.9 & - & 19.0 & - & 9.5 & - & 14.3 & - & 14.3 & - & 0.0 & - & 21 \\
\hline $\begin{array}{l}\text { Early chick } \\
\text { rearing }\end{array}$ & 0.0 & 0.0 & 87.5 & 87.5 & 0.0 & 0.0 & 12.5 & 25.0 & 12.5 & 37.5 & 0.0 & 0.0 & 8 & 8 \\
\hline $\begin{array}{l}\text { Late chick } \\
\text { rearing }\end{array}$ & 0.0 & 0.0 & 0.0 & 0.0 & 0.0 & 0.0 & 0.0 & 0.0 & 0.0 & 0.0 & 94.4 & 100.0 & 54 & 53 \\
\hline 2005 & & & & & & & & & & & & & & \\
\hline Incubation & - & 64.0 & - & 4.0 & - & 24.0 & - & 4.0 & - & 12.0 & - & 0.0 & - & 25 \\
\hline $\begin{array}{l}\text { Early chick } \\
\text { rearing }\end{array}$ & 0.0 & 0.0 & 25.7 & 22.2 & 0.0 & 11.1 & 71.4 & 66.7 & 2.9 & 11.1 & 0.0 & 0.0 & 35 & 18 \\
\hline $\begin{array}{l}\text { Late chick } \\
\text { rearing }\end{array}$ & 0.0 & 0.0 & 6.4 & 4.7 & 0.0 & 0.0 & 0.0 & 0.0 & 0.0 & 2.3 & 93.6 & 95.3 & 47 & 43 \\
\hline
\end{tabular}


Table 2. Results of a Kolmogorov-Smirnov test with the daily patterns of prey occurrence between 2 age categories during the chick-rearing period. There were no significant differences in the daily patterns of prey occurrence between the age categories

\begin{tabular}{|c|c|c|c|c|}
\hline & \multicolumn{2}{|c|}{$-2004-$} & \multicolumn{2}{|c|}{-2005} \\
\hline & $D$ & $\mathrm{p}$ & $D$ & $\mathrm{p}$ \\
\hline Greenling & 0.05 & $>0.99$ & 0.22 & 0.77 \\
\hline 0+ sandlance & 0.00 & $>0.99$ & 0.17 & 0.96 \\
\hline Anchovy & 0.05 & $>0.99$ & 0.11 & $>0.99$ \\
\hline
\end{tabular}

\section{Stable isotope ratio in adult blood plasma}

Stable isotope ratios changed seasonally. Blood plasma $\delta^{15} \mathrm{~N}$ was greater in the late chick-rearing period than in the incubation period in 2004 (Fig. 2, ANOVA: $\left.F_{1,19}=16.6, \mathrm{p}<0.01\right)$. Sample size in the early chick-rearing period in 2004 was too small $(\mathrm{n}=3)$ for statistical analysis. Similarly, blood plasma $\delta^{15} \mathrm{~N}$ was greater in the early and late chick-rearing period than the incubation period and the adjusted $\delta^{15} \mathrm{~N}$ of egg yolk in 2005 (Fig. 2, ANOVA with Scheffé's test: $F_{3,73}=$ 81.6, $\mathrm{p}<0.01)$. In 2004, blood plasma $\delta^{13} \mathrm{C}$ did not differ between the incubation and the late chick-rearing periods (Fig. 2, ANOVA: $F_{1,19}=0.28, \mathrm{p}=0.61$ ). In 2005, blood plasma $\delta^{13} \mathrm{C}$ during the incubation and early chick-rearing periods was higher than in the eggformation and late chick-rearing periods (Fig. 2, ANOVA with Scheffé's test: $F_{3,73}=60.3, \mathrm{p}<0.01$ ).

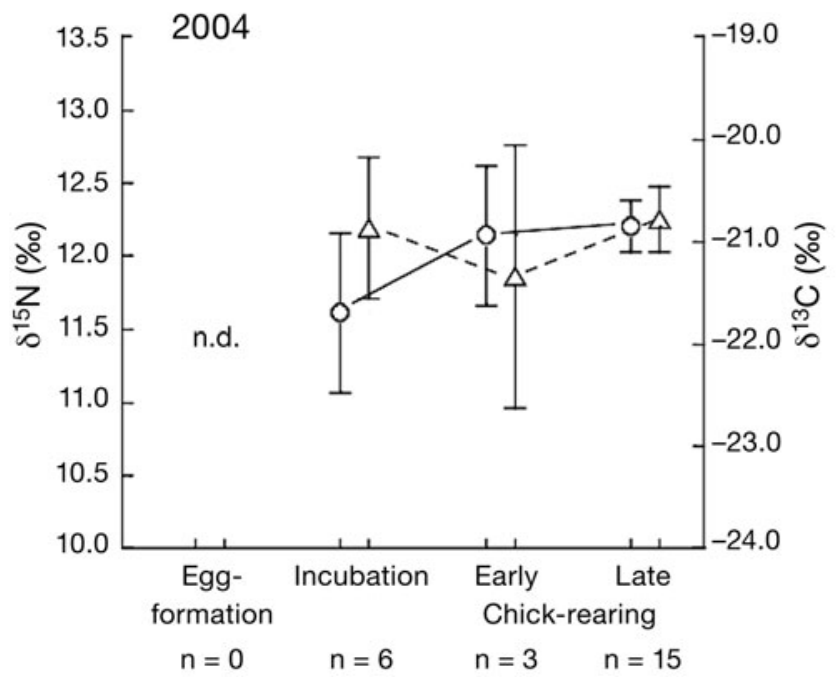

There were inter-annual differences in the stable isotope ratios. Although blood plasma $\delta^{15} \mathrm{~N}$ did not differ between 2004 and 2005 (Fig. 2, ANOVA: incubation period, $F_{1,35}=5.64, \mathrm{p}=0.34$, late chick-rearing period, $F_{1,33}=0.47, \mathrm{p}=0.53$ ), blood plasma $\delta^{15} \mathrm{C}$ was higher in 2005 than 2004 (Fig. 2, ANOVA: incubation period, $F_{1,35}=11.55, \mathrm{p}<0.05$, late chick-rearing period, $F_{1,33}=10.15, \mathrm{p}<0.05$ ).

\section{DISCUSSION}

\section{Diet as determined by stomach contents, stable isotope ratios, and bill-loads}

Diet information based on stomach contents are often biased due to rapid digestion of soft-bodied prey (e.g. crustaceans, Bradstreet 1980) and the long retention of hard body parts (e.g. squid beaks, Wilson et al. 1985). Extrapolated from the retention time in the black guillemot Cepphus grylle and Atlantic puffin Fratercula arctica (2.7 to $3.8 \mathrm{~h}$, Hilton et al. 2000), the stomach contents of the rhinoceros auklets collected on their arrival in the evening may reflect the food ingested about 3 to $4 \mathrm{~h}$ before sunset. In general, euphausiids and fish make diurnal vertical migrations to depths of between 30 and 100 m (Beamish 1965, Scott \& Scott 1988, Iguchi \& Ikeda 2004), and hence they may only be available during a limited time of the day for rhinoceros auklets, which have a maximum dive depth of 52 to $57 \mathrm{~m}$ (Kato et al. 2003, Kuroki et al. 2003). Thus, prey found in the stomach samples can be biased.

Fig. 2. Cerorhinca monocerata. Changes in the blood plasma $\delta^{15} \mathrm{~N}(\mathrm{O})$ and $\delta^{13} \mathrm{C}(\Delta)$ between incubation period, early chick-rearing period, and late chick-rearing period in 2004 and 2005. Data are means \pm 1 SD. Sample sizes (number of birds) are shown below the $x$-axis. $\delta^{15} \mathrm{~N}(O)$ and $\delta^{13} \mathrm{C}(\Delta)$ in the egg-formation period (egg yolk, $x$ ) in 2005 were adjusted by the enrichment factor of blood plasma $(y)$ and that of egg yolk $(z)$ (adjusted value; egg yolk $=x-z+y$ ) to compare to the stable isotope ratio of blood plasma in other periods 
When the enrichment factor for blood plasma $(-1.3 \%$ and $2.8 \%$ for $\delta^{13} \mathrm{C}$ and $\delta^{15} \mathrm{~N}$, this study) and that for egg yolk $\left(0.1 \%\right.$ and $3.4 \%$ for $\delta^{13} \mathrm{C}$ and $\delta^{15} \mathrm{~N}$, Hobson 1995) were subtracted from the measured stable isotope values, blood plasma stable isotope values reflected the prey species found in the stomach contents (Fig. 3). Low $\delta^{15} \mathrm{~N}$ in the egg yolk in 2004 indicated that rhinoceros auklets had fed mainly on euphausiids during the egg-formation period (Figs. $2 \& 3$ ). The $\delta^{15} \mathrm{~N}$ of blood plasma was lower during the incubation period, when the adults fed on fish and euphausiids, than during the chick-rearing period, when they fed only on fish (Fig. 2). The adjusted blood plasma stable isotope values (Fig. 3) appeared to be close to those of $0+$ sandlance in early chick rearing, and close to the mean value of $0+$ sandlance and anchovy in late chick rearing in 2004. In 2005, stable isotope values were between the values of $0+$ sandlance and $0+$ greenling during early chick rearing and closest to that of anchovy during late chick rearing.

The $\delta^{13} \mathrm{C}$ values of $0+$ sandlance and $0+$ greenling were higher in 2005 than in 2004 (Fig. 3). This explains the higher blood plasma levels of $\delta^{13} \mathrm{C}$ in 2005 than 2004. For example, in the Bering Sea, inter-annual variations of $\delta^{13} \mathrm{C}$ in the marine food web were found in the late 1990s (Schell et al. 1998, Brodeur et al. 2002). These changes in $\delta^{13} \mathrm{C}$ in the Bering Sea may be caused by changes in the pattern of primary production, especially coccolithophore blooms with high $\delta^{13} \mathrm{C}$ ratios (Napp \& Hunt 2001, Stockwell et al. 2001), as suggested by Brodeur et al. (2002). No data on the pat- terns of primary production in our region were available, although the inter-annual difference in patterns of primary production (possibly not by coccolithophore blooms in our region) may be the cause of the interannual difference in $\delta^{13} \mathrm{C}$ in auklets and prey species. The overall agreement of the prey composition, as estimated by stomach sampling and blood stable isotope ratios, thus suggests that the stomach samples were not particularly biased on average, and thus can be useful in assessing adult diet.

Differences in adult and chick diets provide a potential impediment to assessing the relationship between oceanographic change and seabird breeding status. Adults of thick-billed murres Uria lomvia, common murres $U$. aalge, black guillemot, rhinoceros auklets in Canada, roseate terns Sterna dougallii, and Arctic terns $S$. paradisaea feed on smaller and lower quality prey that are easy to collect for their own consumption, but feed chicks with large, high quality prey (Gaston \& Nettleship 1981, Davoren \& Burger 1999, Ramos 2000, Butler \& Buckley 2002, Hatch 2002, Wilson et al. 2004). However, we found that the differences in prey species for adults and chicks were not significant in rhinoceros auklets on Teuri Island. These differences, i.e. whether the diet of adults and chicks are similar, may reflect regional differences in prey availability or differences in how fish are carried in the bill. Single-prey loaders, such as murres and terns, bring back a single prey item in their bill on each trip, whereas multiple-prey loaders such as puffins and rhinoceros auklets bring back multiple prey items per trip. Prey selection might be more
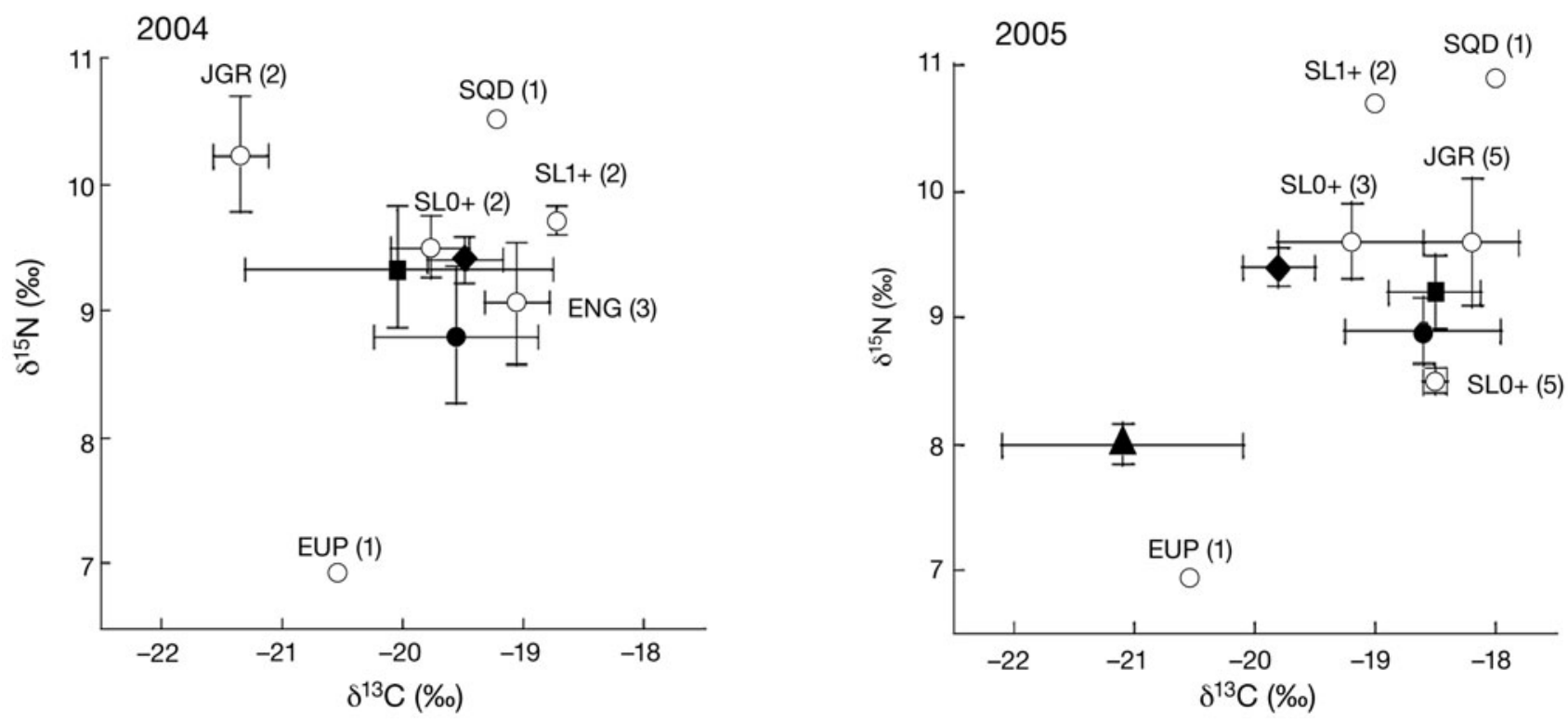

Fig. 3. Adjusted $\delta^{15} \mathrm{~N}$ and $\delta^{13} \mathrm{C}$ of egg yolk $(\mathbf{\Delta})$ and those of blood plasma during incubation ( $)$, early chick-rearing ( $\left.\mathbf{\square}\right)$, and late chick-rearing period $(\diamond)$ in 2004 and 2005. Stable isotope ratios of prey (SL0+: 0+ sandlance, SL1+: >1+ sandlance, JGR: greenling, SQD: squid, ENG: anchovy) collected in 2004 and 2005 are also shown (O). Euphausiids (EUP) were collected only in 2003, and their stable isotope ratios are shown in both panels. Data are means $\pm 1 \mathrm{SD}$. Sample sizes are on the symbols 
sensitive in single-prey loaders, since adults must select 1 large fish to maximize their food load (Wilson et al. 2004). Although the reasons remain unknown, the diets of adults and chicks of rhinoceros auklets in our region showed similar seasonal and inter-annual changes, and presumably reflect the strong influence of marine environmental change.

\section{Seasonal and inter-annual changes in diet and the marine environment}

Only a single study to date has reported euphausiids in the stomachs of adult rhinoceros auklets during the non-breeding season (Ainley \& Sanger 1979). Our study is the first to demonstrate that 'piscivorous' rhinoceros auklets may feed on substantial quantities of euphausiids during the early breeding season, i.e. during the egg-formation and incubation periods. This finding was similar to the result that tufted puffin Fratercula cirrhata, a closely related 'piscivorous' seabird, forages for a lower trophic diet before chick hatching (Williams et al. 2008). Diets during egg formation and incubation may determine the timing of breeding, clutch size, or egg quality and parental body condition in seabirds (Chastel et al. 1995, Oro et al. 1996, Barbraud \& Chastel 1999, Gasparini et al. 2007), and consequently affect reproductive success. Sorenson et al. (2009) reported that Cassin's auklet Ptychoramphus aleuticus laid larger eggs earlier and had higher fledging success in years when females fed on lower trophic level crustaceans than in years when females fed on higher trophic level fish. One of the possible benefits to seabirds of eating crustaceans such as euphausiids might be the intake of carotenoids. Carotenoids are widely used by animals as red and yellow pigments (Møller et al. 2000), but are also hypothesized to enhance antioxidant activity and immune function (Chew 1996, Blount et al. 2002). Euphausiids contain large quantities of carotenoids (Fisher et al. 1955) that accumulate in seabird eggs through trophic effects (Blount et al. 2002). Our study suggests that euphausiids, which are lower trophic level crustaceans and highly seasonal in the northern Sea of Japan, could be an important factor in the breeding performance of rhinoceros auklets. Thus, the dynamics of euphausiid stocks and whether the birds time their egg-laying to match euphausiid blooms appear to have a critical effect on seabird populations.

We predicted that parents would select euphausiids, perhaps the prey easiest to collect, not only during egg formation and incubation, but also during chick rearing, for themselves. However, in this study, during the incubation period, rhinoceros auklets switched their prey from euphausiids to fish and did not feed on euphausiids during the chick-rearing period. In the Arctic, sub-Arctic, and Antarctic regions, euphausiids are available at the sea surface throughout the summer, coinciding with the seabird breeding season (e.g. Coyle \& Cooney 1993, Everson 2000, Coyle 2005). In the Bering Sea, many seabirds forage for euphausiids during the summer (Gaston \& Jones 1998, Brooke 2004, Hunt et al. 2008). On the other hand, in the temperate regions such as the sea around Japan, including the study area, euphausiids are available at the sea surface for only a short period in the early spring, since they descend to deep, cool water when the surface water temperature increases in the summer (Endo 1984, Hanamura et al. 1989, Iguchi \& Ikeda 2004). The euphausiids Thysanoessa longipes and T. inermis, the main prey of auklets in the early spring in this study, are found at the sea surface (less than $30 \mathrm{~m}$ deep) in the northern part of the Sea of Japan only in March and April (Hanamura et al. 1989, Iguchi \& Ikeda 2004). In the waters around Teuri Island, T. inermis forms dense spawning swarms at the sea surface in the early spring, and then descends to deeper water $(>100 \mathrm{~m})$ in the summer when the SST rises to over $8^{\circ} \mathrm{C}$ in May (Hanamura et al. 1989), becoming unavailable to rhinoceros auklets. Seasonal changes in SST during early spring around the colony in 2004 and 2005 were consistent with the timing of the auklet diet switching: the shift from euphausiid to non-euphausiid prey coincided with the date that SSTs in the auklets' foraging range rose above $8^{\circ} \mathrm{C}$, i.e. Days 40 to 55 (10 to 25 May) (Figs. 1, 4 \& 5). In addition, euphausiid species differed between 2004 and 2005. In 2004, all identifiable euphausiids were T. longipes. In contrast, in 2005, all euphausiids were $T$. inermis. This latter species is the dominant spawning swarm-forming euphausiid around Teuri Island in March to April (Hanamura et al. 1989) and hence is fed on by many species of seabird (e.g. black-tailed gull Larus crassirostris, Tomita et al. 2009). However, in 2004, the total catch of $T$. inermis in commercial fisheries around Teuri Island was less than $20 \%$ of that in normal years (N. Tomita unpubl.), suggesting a shortage of $T$. inermis. We believe that $T$. longipes might have been fed on by auklets during the egg-formation and incubation periods as an alternative prey, due to a shortage of $T$. inermis, the ordinarily dominant euphausiid, during 2004.

During the chick-rearing period, adult auklets fed themselves and their chicks $0+$ sandlance and $0+$ greenling for the first couple of weeks, and then switched to anchovy. The Japan sea greenling is a cold-water fish inhabiting the Sea of Japan off Hokkaido. It spawns around Rishiri Island, Rebun Island, and Musashi Bank (60 to $90 \mathrm{~km}$ north of Teuri Island) in winter, after which $0+$ greenling move to the Okhotsk Sea in June when the SST rises (Shimazaki \& Kyushin 
Distribution of $8^{\circ} \mathrm{C}(\mathrm{SST})$ water in 2004

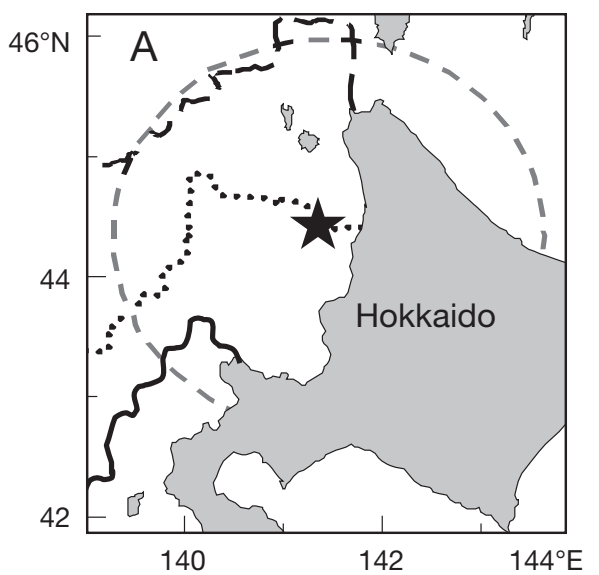

Distribution of $13^{\circ} \mathrm{C}(\mathrm{SST})$ water in 2004

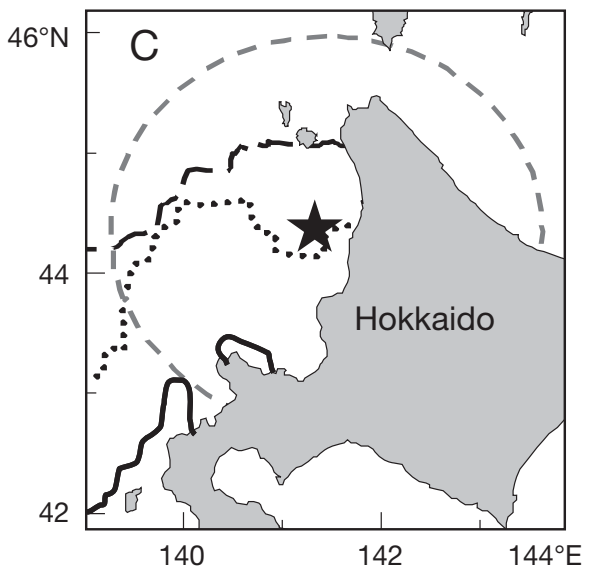

Distribution of $8^{\circ} \mathrm{C}(\mathrm{SST})$ water in 2005

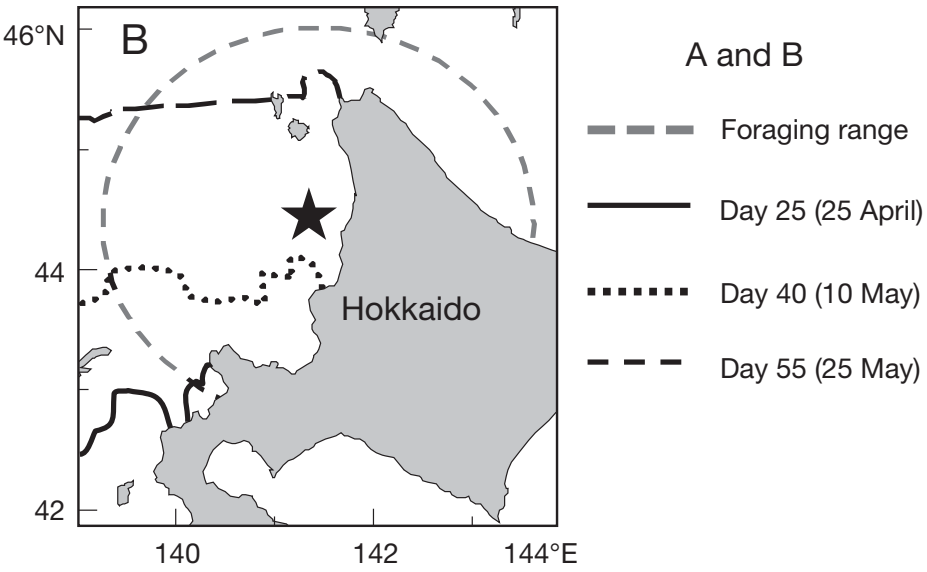

Distribution of $13^{\circ} \mathrm{C}(\mathrm{SST})$ water in 2005

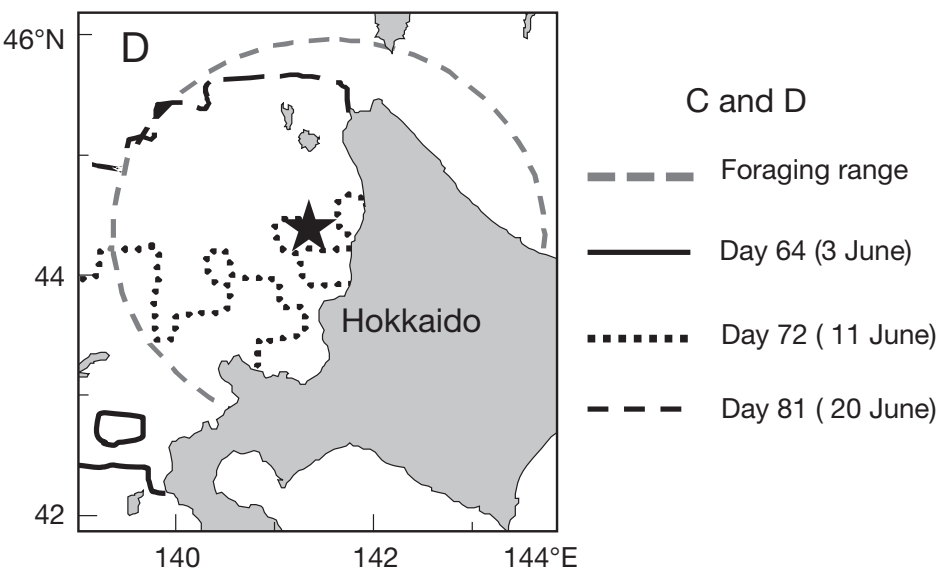

Fig. 4. Northward expansion of the distribution of $8^{\circ} \mathrm{C}$ and $13^{\circ} \mathrm{C} \mathrm{SST}$. (A,B) Boundary of the $8^{\circ} \mathrm{C}$ water on Day $25(25$ April, the day euphausiids mainly appeared in stomachs of auklets both in 2004 and 2005; solid line), on Day 40 (10 May, approximate timing of diet switching from euphausiids to other fish species in 2004 and 2005; dotted line), and Day 55 (25 May, dashed line) in 2004 and 2005. (C,D) Boundary of the $13^{\circ} \mathrm{C}$ water on Day 64 (3 June, the day anchovy first appeared in bill loads in 2004; solid line), on Day 72 (11 June, the day anchovy first appeared in bill loads in 2005; dotted line), and Day 81 (20 June, broken line) in 2004 and 2005. Data, analyzed by the Japan Meteorological Agency, were obtained from the NEAR-GOOS data base, JODC: http://near-goos1.jodc.go.jp/index.html. Broken gray circle shows the potential maximum foraging range of rhinoceros auklets (164 km; Kato et al. 2003). ^: Teuri Island

1982, Nagasawa \& Torisawa 1991). 0+ sandlance are heavily harvested by commercial fisheries in April to June around the shore areas in Hokkaido, including Teuri Island (Nagasawa \& Torisawa 1991). Sandlance move shorter distances than greenling, although they also move to northern areas when the SST rises in summer (Department of Fisheries and Forestry in Hokkaido 2004). Therefore, as the SST increases during the chick-rearing period (Figs. 4 \& 5), the availability of those fish species may decrease. In contrast, in the coastal area of Hokkaido, the anchovy is a warmwater species that appears in water with an SST of 12 to $15^{\circ} \mathrm{C}$ (Mihara 1998). The availability of anchovy may therefore increase with the seasonal increase in SST around Teuri Island. The maximum potential foraging range of rhinoceros auklets breeding on Teuri Island can be assumed to be $164 \mathrm{~km}$ from Teuri Island (Kato et al. 2003, see Fig. 4). The timing of prey switching to anchovy in 2004 and 2005 was consistent with the time that the $13^{\circ} \mathrm{C} \mathrm{SST}$ water arrived at the southern edge of their maximum foraging range (Figs. 4 \& 5). Furthermore, the timing of the switch to anchovy differed between the 2 years, i.e. Day 65 (4 June) in 2004 and Day 75 (14 June) in 2005, 10 d later in 2005 than 2004. The strength of the Tsushima Current in the Sea of Japan (monthly anomalous flow rate of Tsushima Current in the Japan Sea coast off Maizuru, central Sea of Japan) during May to June was approximately 57\% 

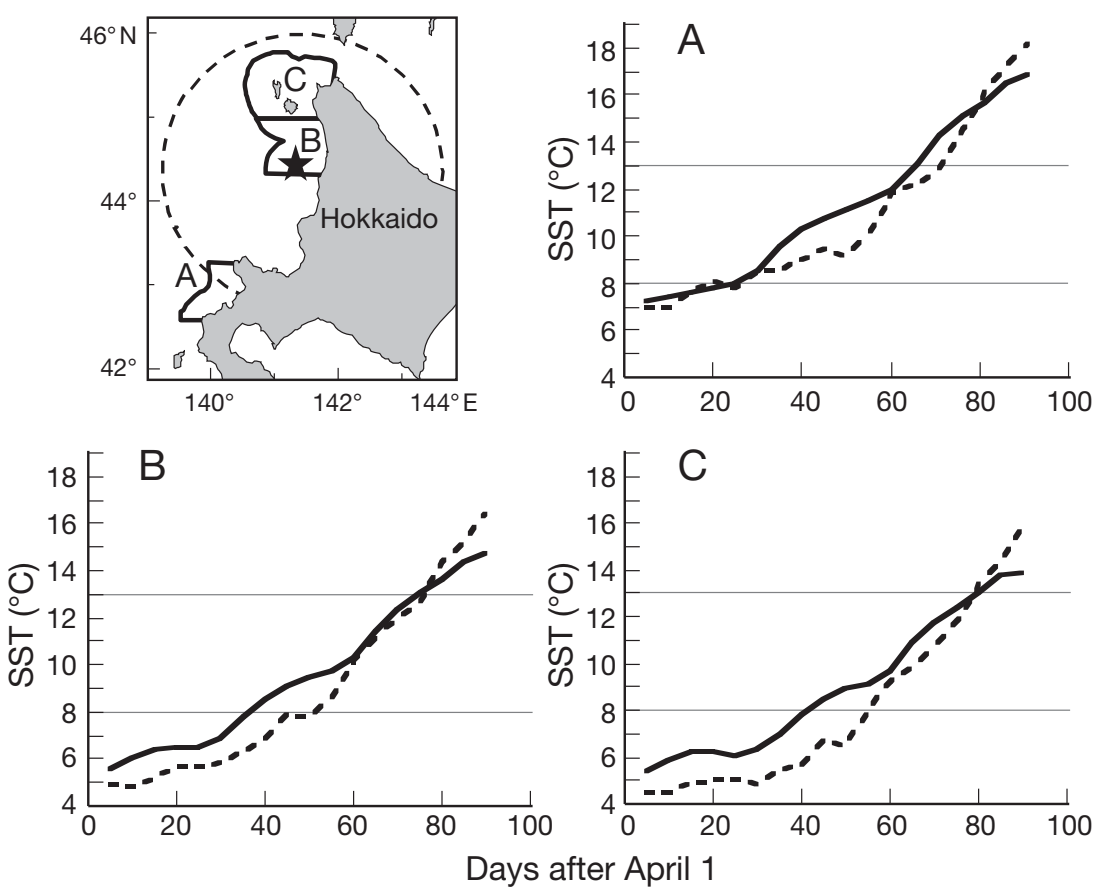

Fig. 5. Daily changes of SSTs (A) at the southern edge of the foraging range of rhinoceros auklets (western Shiribeshi region), (B) around Teuri Island (northern Rumoi region), and (C) at the northern edge of the foraging range of auklets (Soya region), and mean daily SSTs (satellite) in the area shown in the map. Data in (A), (B) and (C) were obtained from the Hakodate Marine Observatory (www.data.kishou.go.jp/kaiyou/db/hakodate/finesstHK/finesstHK.html). Sampling date was calculated from 1 April. Solid (dotted) line shows SSTs in 2004 (2005). Thin horizontal lines show the SSTs $8^{\circ} \mathrm{C}$ (indicator of euphausiid dispersal) and $13^{\circ} \mathrm{C}$ (indicator of anchovy arrival). $\star$ : Teuri Island
In conclusion, quick switching in adult diets from euphausiids to fish species and then in both adult and chick diets to anchovy was consistent with the seasonal and inter-annual changes in the arrival of warm water. The current-related rapid change in the local marine food web structure appears to induce drastic changes in the trophic condition of the rhinoceros auklet and forces an active response with respect to foraging behavior and prey selection; it might consequently affect the breeding output of auklets. Hence, this study also suggests the potential usefulness of using the prey switching of rhinoceros auklets, a highly mobile marine top predator, as a sensitive indicator of local marine environmental change. Furthermore, our study is the first to shed light on the diet during the egg-formation and egg-laying periods, among the most important periods that determine breeding output, in rhinoceros auklets, which in turn helps to understand the interactions between population dynamics of marine top predators and local and global-scale oceanographic changes. stronger in 2004 than 2005 (Japan Meteorological Agency: www.data.kishou.go.jp). The cooler SST in 2005, compared to that in 2004, during the breeding season (Fig. 5) also indicates a stronger flow rate of the Tsushima Current during 2004. This would be the reason for the annual differences of the timing of auklets switching prey to anchovy. Anchovy is the most energy-rich diet for auklet chicks in this region (Takahashi et al. 2001), therefore the auklets switched their diet for both themselves and their chicks when anchovies became available around their colony. Further, parents may switch their prey to anchovy as quickly as possible, since anchovy is a highly nutritious diet for their chicks (Takahashi et al. 2001). In this study, parents switched to anchovy ( 0 to $>50 \%$ occurrence) within only 8 d in 2004 and within 10 d in 2005 (Fig. 1). These switching speeds were faster than the intrusion speed of the Tsushima Current, which was extrapolated from daily changes in SST within the foraging range of auklets (Fig. 5). Parents may actively focus their foraging efforts in areas where anchovies are first available when they arrive within the maximum foraging range of the auklets.
Acknowledgements. We appreciate the field support from N. Tomita, D. Ochi, Y. Manabe, A. Saito, Y. Inoue, and R. Komatsu. Dr. Y. Sakurai and members of the Laboratory of Marine Ecology, Graduate School of Fisheries Science, Hokkaido University, provided useful comments during the course of the study. We thank M. Aotsuka and Y. Kusakabe for logistical support on the island. We thank Dr. G. Hunt for precise English editing and valuable comments on the manuscript. Dr. A. Takahashi, Dr. Y. Niizuma, K. Kazama and Y. Shibata provided valuable comments on the manuscript. The work was supported by a Japan Society for the Promotion of Science Grant-in Aid for Scientific Research $(17370007,16108002)$ and the Centers of Excellence Program (Neo Natural History) led by Prof. Okada, Hokkaido University. Permission to work on the island and sample eggs was granted by the Japanese Environmental Agency (permit nos. 040315003, 050318001) and the Agency for Cultural Affairs (permit no. 16-4-1810).

\section{LITERATURE CITED}

Ainley DG, Sanger GA (1979) Trophic relations of seabirds in the northeastern Pacific Ocean and Bering Sea. In: Bartonek JC, Nettleship DN (eds) Conservation of marine birds of northern North America. US Fish Wildl Serv Res Rep 11:95-122 
Barbraud C, Chastel O (1999) Early body condition and hatching success in the snow petrel Pagodroma nivea. Polar Biol 21:1-4

Barrett RT, Furness RW (1990) The prey and diving depths of seabirds on Hornoy, North Norway after a decrease in the Barents Sea capelin stocks. Ornis Scand 21:179-186

Beamish FWH (1965) Vertical migration by demersal fish in the Northwest Atlantic. J Fish Res Board Can 23: 109-139

Blount JD, Surai PF, Nager RG, Houston DC, Møller AP, Trewby ML, Kennedy MW (2002) Carotenoids and egg quality in the lesser black-backed gull Larus fuscus: a supplemental feeding study of maternal effects. Proc R Soc Lond B Biol Sci 269:29-36

Bost CA, Koubbi P, Genevois F, Ruchon L, Ridoux V (1994) Gentoo penguin Pygoscelis papua diet as an indicator of planktonic availability in the Kerguelen Islands. Polar Biol 14:147-153

Boyd IL, Wanless S, Camphusysen CJ (2006) Top predators in marine ecosystems: their role in monitoring and management. Cambridge University Press, London

Bradstreet MSW (1980) Thick-billed murres and black guillemots in the Barrow Strait area, N.W.T., during spring: diets and food availability along ice edges. Can J Zool 58: 2120-2140

Brodeur RD, Sugisaki H, Hunt GL Jr (2002) Increases in jellyfish biomass in the Bering Sea: implications for the ecosystem. Mar Ecol Prog Ser 233:89-103

Brooke ML (2004) Albatrosses and petrels across the world. Oxford University Press, New York

Burger AE, Wilson RP, Garnier D, Wilson MPT (1993) Diving depth, diet, and underwater foraging of rhinoceros auklets in British Columbia. Can J Zool 71:2528-2540

Butler RG, Buckley DE (2002) Black guillemot, Cepphus grylle (Charadriiformes, Alcidae). Birds of North America No. 675, Buteo Books, Shipman, VA

> Chastel O, Weimerskirch H, Jouventin P (1995) Body condition and seabird reproductive performance: a study of three petrel species. Ecology 76:2240-2246

Cherel Y, Ridoux V, Rodhouse PG (1996) Fish and squid in the diet of King Penguin chicks, Aptenodytes patagonicus, during winter at sub-antarctic Crozet Islands. Mar Biol 126:559-570

Chew BP (1996) Importance of antioxidant vitamins in immunity and health in animals. Anim Feed Sci Technol 59: 103-114

Chihara M, Murano M (1997) An illustrated guide to marine plankton in Japan. Tokai University Press, Tokyo

Coyle KO (2005) Zooplankton distribution, abundance and biomass relative to water masses in eastern and central Aleutian Island passes. Fish Oceanogr 14:77-92

Coyle KO, Cooney RT (1993) Water column sound scattering and hydrography around the Pribilof Islands, Bering Sea. Cont Shelf Res 13:803-827

> Davoren GK, Burger AE (1999) Differences in prey selection and behaviour during self-feeding and chick provisioning in rhinoceros auklets. Anim Behav 58:853-863

Deguchi T, Watanuki Y, Niizuma Y, Nakata A (2004) Interannual variations of the occurrence of epipelagic fish in the diets of the seabirds breeding on Teuri Island, northern Hokkaido, Japan. Prog Oceanogr 61:267-275

Department of Fisheries and Forestry in Hokkaido (2004) Manual for fisheries resource management in Hokkaido 2004. Department of Fisheries and Forestry in Hokkaido, Sapporo (in Japanese)

Deuel HJ (1955) The lipids II: biochemistry, digestion, absorption, transport and storage. Interscience, New York
Durant JM, Anker-Nilssen T, Stenseth NC (2003) Trophic interactions under climate fluctuations: the Atlantic puffin as an example. Proc R Soc Lond B Biol Sci 270: 1461-1466

Endo Y (1984) Daytime surface swarms of the Euphausia pacifica (Crustacea: Euphausiacea) in the Sanriku coastal waters off northeastern Japan. Mar Biol 79:269-276

Everson I (2000) Fish and aruatic resources Ser 6: krill biology, ecology and fisheries. Blackwell Science, Oxford

Fisher LR, Kon SK, Thompson SY (1955) Vitamin A and carotenoids in certain invertebrates. III. Euphausiacea. J Mar Biol Assoc UK 34:81-100

Forero MG, Hobson KA (2003) Using stable-isotopes of nitrogen and carbon to study seabird ecology: applications in the Mediterranean seabird community. Sci Mar 67:23-32

Casparini J, Boulinier T, Gill VA, Gil D, Hatch SA, Roulin A (2007) Influence of body condition on reproductive decision and reproductive success in the blue petrel. J Evol Biol 20:874-880

Gaston AJ, Jones IL (1998) The auks. Oxford University Press, New York

Gaston AJ, Nettleship DN (1981) Thick-billed murres of Prince Leopold Island. Can Wild Serv Monogr Ser 6

Gjerdrum C, Vallee AMJ, St Clair CC, Bertram DF, Ryder JL, Blackburn GS (2003) Tufted puffin reproduction reveals ocean climate variability. Proc Natl Acad Sci USA 100: 9377-9382

Guinet C, Chastel O, Koudil M, Durbec JP, Jouventin P (1998) Effects of warm sea-surface temperature anomalies on the blue petrel at the Kerguelen islands. Proc R Soc Lond B Biol Sci 265:1001-1006

> Hanamura Y, Kotori M, Hamaoka S (1989) Daytime surface swarms of the Euphausiid Thysanoessa inermis off the west coast of Hokkaido, northern Japan. Mar Biol 102: 369-376

Harris MP, Wanless S (1985) Fish fed to young guillemots, Uria aalge, and used in display on the Isle of May, Scotland. J Zool (Lond) 207:441-458

Hatch JJ (2002) Arctic tern, Sterna paradisaea (Charadriiformes, Alcidae). Birds of North America No. 707, Buteo Books, Shipman, VA

Hilton GM, Furness W, Houston DC (2000) A comparative study of digestion in North Atlantic seabirds. J Avian Biol 31:36-46

> Hobson KA (1993) Trophic relationships among high Arctic seabirds: insights from tissue-dependent stable-isotope models. Mar Ecol Prog Ser 95:7-18

> Hobson KA (1995) Reconstructing avian diets using stablecarbon and nitrogen isotope analysis of egg components - patterns of isotopic fractionation and turnover. Condor 97:752-762

Hobson KA, Clark RG (1992a) Assessing avian diets using stable isotopes. I: Turnover of ${ }^{13} \mathrm{C}$ in tissues. Condor 94: 181-188

> Hobson KA, Clark RG (1992b) Assessing avian diets using stable isotopes. II. Factors influencing diet-tissue fractionation. Condor 94:189-197

Hobson KA, Clark RG (1993) Turnover of ${ }^{13} \mathrm{C}$ in cellular and plasma fractions of blood: implications for nondestructive sampling avian dietary studies. Auk 110:638-641

> Hobson KA, Piatt JF, Pitocchelli J (1994) Using stable isotopes to determine seabird trophic relationships. J Anim Ecol 63: 786-798

> Hunt GL Jr, Stabeno PJ, Strom S, Napp JM (2008) Patterns of spatial and temporal variation in the marine ecosystem of the southeastern Bering Sea, with special reference to the Pribilof Domain. Deep-Sea Res II 55:1919-1944 
Iguchi N, Ikeda T (2004) Vertical distribution, population structure and life history of Thysanoessa longipes (Crustacea: Euphausiacea) around Yamato Rise, Central Japan Sea. J Plankton Res 26:1015-1023

Ishikawa K, Watanuki Y (2002) Sex and individual differences in foraging behavior of Japanese cormorants in years of different prey availability. J Ethol 20:49-54

Kato A, Watanuki Y, Naito Y (2003) Foraging behaviour of chick-rearing rhinoceros auklet Cerorhinca monocerata on Teuri Island, Japan, determined by acceleration-depth recording micro data loggers. J Avian Biol 34:282-287

Kitaysky AS, Golubova EG (2000) Climate change causes contrasting in reproductive performance of planktivorous and piscivorous alcids. J Anim Ecol 69:248-262

Kuroki M, Kato A, Watanuki Y, Niizuma Y, Takahashi A, Naito Y (2003) Diving behavior of an epipelagically-feeding alcid, the rhinoceros auklet (Cerorhinca monocerata). Can J Zool 81:1249-1256

Lewis S, Wanless S, Wright PJ, Harris MP, Bull J, Elston DA (2001) Diet and breeding performance of black-legged kittiwakes Rissa tridactyla at a North Sea colony. Mar Ecol Prog Ser 221:277-284

Litzow MA, Piatt JF, Prichard AK, Roby DD (2002) Response of pigeon guillemots to variable abundance of high-lipid and low-lipid prey. Oecologia 132:286-295

Mihara Y (1998) Distribution of the Japanese anchovy, Engraulis japonicus, off southeastern Hokkaido. Sci Rep Hokkaido Fish Exp Stn 53:9-14

Møller AP, Biard C, Blount JD, Houston DC, Ninni P, Saino N, Surai PF (2000) Carotenoid-dependent signals: indicators of foraging efficiency, immunocompetence or detoxification ability? Avian Poult Biol Rev 11:137-159

Naganuma K (2000) The Sea of Japan as the natural environment of marine organisms. Bull Japan Sea Natl Fish Res Ins 50:1-42

Nagasawa K, Torisawa M (1991) Fish and marine invertebrates of Hokkaido: biology and fisheries. Kita-nihon Kaiyo Center, Sapporo (in Japanese)

Nakabo T (ed) (1993) Fish of Japan with pictorial keys to the species. Tokai University Press, Tokyo

Nakata A, Tanaka I (2002) Seasonal and year-to-year variability of baroclinic volume transport of the Tsushima Warm Current, off the west of Hokkaido. Sci Rep Hokkaido Fish Exp Stn 63:1-8

Napp JM, Hunt GL Jr (2001) Anomalous conditions in the SE Bering Sea, 1997: linkages among climate, weather, ocean, and biology. Fish Oceanogr 10:61-68

Orians GH, Pearson NE (1979) On the theory of central place foraging. In: Horn DJ, Stairs GR, Mitchell R (eds) Analysis of ecological systems. Ohio State University Press, Columbus, OH, p 155-177

Oro D, Jover L, Ruiz X (1996) Influence of trawling activity on the breeding ecology of a threatened seabird, Audouin's gull Larus audouinii. Mar Ecol Prog Ser 139:19-29

Osa Y, Watanuki Y (2002) Status of seabirds breeding in Hokkaido. J Yamashina Inst Ornithol 33:107-141

Ramos JA (2000) Characteristics of foraging habitats and chick food provisioning by tropical roseate terns. Condor 102:795-803

Submitted: November 24, 2008; Accepted: July 1, 2009
Schell DM, Barnett BA, Vinette KA (1998) Carbon and nitrogen isotope ratios in zooplankton of the Bering, Chukchi, and Beaufort seas. Mar Ecol Prog Ser 162:11-23

Scott WB, Scott MG (1988) Atlantic fishes of Canada. Can Bull Fish Aquat Sci 219

Shimazaki K, Kyushin K (1982) On the population of the young Japan Sea greenling, Pleurogrammus azonus Jordan et Metz, in the Okhotsk Sea. Bull Fac Fish Hokkaido Univ 33:229-239

Sorensen MC, Hipfner JM, Kyser TK, Norris DR (2009) Carryover effects in a Pacific seabird: stable isotope evidence that pre-breeding diet quality influences reproductive success. J Anim Ecol 78:460-467

> Stockwell DA, Whitledge TE, Zeeman SI, Coyle KO and others (2001) Anomalous conditions in the SE Bering Sea, 1997: nutrients, phytoplankton, and zooplankton. Fish Oceanogr 10:99-116

> Takahashi A, Kuroki M, Niizuma Y, Watanuki Y (1999) Parental food provisioning is unrelated to manipulated offspring food demand in a nocturnal single-provisioning alcid, the rhinoceros auklet. J Avian Biol 30:486-490

> Takahashi A, Kuroki M, Niizuma Y, Kato A, Saitoh S, Watanuki Y (2001) Importance of the Japanese anchovy (Engraulis japonicus) to breeding rhinoceros auklets (Cerorhinca monocerata) on Teuri Island, Sea of Japan. Mar Biol 139:361-371

Tameishi H, Nakazono H, Saito K, Takahashi K (1999) Movement of spring blooming in the Sea of Japan monitored with OCTS; application to the pink salmon fishery. Kaiyo Monthly 345:170-176 (in Japanese)

> Thayer JA, Sydeman WJ (2007) Spatio-temporal variability in prey harvest and reproductive ecology of a piscivorous seabird, Cerorhinca monocerata, in an upwelling system. Mar Ecol Prog Ser 329:253-265

Tomita N, Niizuma Y, Takagi M, Ito M, Watanuki Y (2009) Effect of interannual variations in sea-surface temperature on egg-laying parameters of black-tailed gulls (Larus crassirostris) at Teuri Island, Japan. Ecol Res 24:157-162

- Wanless S, Frederiksen M, Daunt F, Scott BE, Harris MP (2007) Black-legged kittiwakes as indicators of environmental change in the North Sea: evidence from long-term studies. Prog Oceanogr 72:30-38

Watanuki Y (1987) Breeding biology and food of rhinoceros auklets on Teuri Island, Japan. Proc NIPR Symp Biol 1: $175-183$

Williams CT, Iverson SJ, Buck CL (2008) Stable isotopes and fatty acid signatures reveal age- and stage-dependent foraging niches in tufted puffins. Mar Ecol Prog Ser 363: $287-298$

Wilson RP (1984) An improved stomach pump for penguins and other seabirds. J Field Ornithol 55:109-112

Wilson RP, La Cock GD, Wilson MP, Mollagee F (1985) Differential digestion of fish and squid in jackass penguins, Spheniscus demersus. Ornis Scand 16:77-79

Wilson LJ, Daunt F, Wanless S (2004) Self-feeding and chick provisioning diet differ in the common guillemot Uria aalge. Ardea 92:197-208

Ydenberg RC (1994) The behavioral ecology of provisioning in birds. Ecoscience 1:1-14

Proofs received from author(s): October 2, 2009 